\title{
The Architecture of Carbon Markets: Institutional analysis of the organizations and relationships that build the market
}

\author{
Janelle Knox-Hayes, Centre for Employment, Work and Finance, Oxford University \\ Centre for the Environment, South Parks Rd., Oxford OX1 3QY, UK and Georgia Institute of \\ Technology, School of Public Policy, 685 Cherry Street, Atlanta, GA 30332 \\ Contact. Janelle.knox@ouce.ox.ac.uk
}

\begin{abstract}
Countries around the world are developing carbon emissions markets as a governance mechanism to reduce greenhouse gas emissions and mitigate anthropogenic climate change. These markets are social institutions, designed to solve the transnational collective action problem of climate change. This article explores the development of carbon markets from an institutional perspective to understand how market networks specifically and social institutions in general are constructed. Drawing on seminal work by Richard Scott and Neil Fligstein, this article explores the way in which organizations build the institution of the carbon markets. As this article aims to demonstrate, a number of public and private organizations, rather than regulatory bodies, build and operationalize the market. The article analyzes how organizations develop the three pillars of the carbon market institution: regulative, normative and culturalcognitive constructs. Since organizations build the institutional pillars of the carbon market network, the strength of the institution cannot be determined by regulation alone. Certainly regulation gives the carbon markets credibility, but their ability to become an institution of common practice relies on the strength and embeddedness of the organizations that build them. The article concludes by suggesting that the carbon market institution serves to communicate and disseminate a common social value of reducing emissions.
\end{abstract}

Keywords: Carbon Markets, Market Development, Institutional Theory JEL classifications: G28, P16, Q56

Acknowledgements. The author would like to thank the many institutions and individuals who participated in the study and made this research possible. The author would also like to thank Gordon Clark and Jarrod Hayes for helpful comments on the article. Support for this research was provided by the National Science Foundation and the Jack Kent Cooke Foundation. None of the above should be held responsible for errors, omissions or any opinions expressed herein. 


\section{Introduction}

One of the defining aspects of the past two hundred years has been the rapid evolution of technology. No less significant, however, have been the remarkable changes in social institutions. ${ }^{i}$ Complex, interwoven institutions of wide scope and effect govern and structure a broad range of social activities, from formal education to employment to social engagement and consumption. These institutions come in many forms and sizes and represent a form of control and organization for ever greater collective integration. As technology facilitates the globalization of both behavior and its consequences, the need for greater and more extensive globalized social institutions increases. As such, institutions both structure behavior and expectation in collectives as well as provide resources for the solution of globalized problems.

Climate change presents one of the largest collective problems confronting governments and societies today. In response, countries around the world are developing carbon emissions markets as a governance mechanism to reduce greenhouse gas emissions. ${ }^{i i}$ These markets follow the design of the relatively successful U.S. acid rain program to reduce sulfur dioxide (MacKenzie, 2007). A number of carbon markets are in existence including the European Union Emissions Trading Scheme (EU ETS) and the Regional Greenhouse Gas Initiative (RGGI) in the northeastern states United States. These markets operate by capping greenhouse gas emissions among utilities and heavy emitters. Compliance parties must demonstrate emissions reductions or trade allowances or offsets to meet compliance targets (Skjurseth \& Wettestad, 2007; Watanabe \& Robinson, 2005). Even though carbon markets differ from other markets in terms of the scope of government involvement - the commodity of exchange is a regulatory creation and emissions reductions are registered and verified by government—carbon reductions trade like other commodities (Capoor \& Ambrosi, 2008; Carr \& Rosembuj, 2007; Hasselknippe, 2003). ${ }^{\text {iii }}$ These markets are social institutions (Callon, 1998), designed to solve the global collective action problem of climate change. This paper seeks to explore the development of carbon emissions markets from an institutional perspective to understand how markets specifically and social institutions in general are constructed.

Drawing on sociology and institutional theory this paper treats the developing carbon market network as a social institution (Knorr-Cetina \& Preda, 2005; Callon, 1998). Seminal work by Richard Scott and Neil Fligstein has produced insight on how social institutions affect the development of the organizations that operate within markets. Reversing the causal arrow, this paper explores the way in which already existing organizations build the institution of the carbon markets. Carbon markets provide a unique opportunity to understand the development of institutions because they represent one of the few modern examples of the wholesale construction of an institution. They are also unique because-as regulatory constructs - the carbon markets represent the purposeful fusion of two institutional meta-structures: government and economy. However, as this article aims to demonstrate, it is not regulatory bodies that truly construct the market institution. Rather, a number of public and private organizations, ranging from development agencies to legal firms and banks build and operationalize the market. Government bodies can provide the impetus for carbon markets, but this merely defines the concept. It is organizations which construct the social meaning and material substance of the market.

The arguments of the article are supported by the use of cases studies of carbon market organizations in Europe and the U.S. and close dialogue-interviews guided by a pre-determined set of questions and conducted on a confidential basis with no citation rights (Clark, 1998). In this study, the cases are built over the course of over multiple interviews with policy makers, 
experts from banks, brokerages, intermediaries, legal firms, consultancies, and wire services in Washington D.C. San Francisco, Los Angles, London and New York. This article proceeds in five sections. Section 2 reviews literature in economic geography and institutional theory to build a framework for understanding the institution of markets, including the pillars (regulative, normative, and cultural-cognitive) that support the institution and the carriers (property rights, governance) that testify to existence. Section 3 explains the methodology used to conduct the study. Section 4 discusses the development of the regulative pillar of the carbon market. Section 5 explores the organizations and processes which develop the normative pillar of the institution. Section 6 provides an overview of the construction of the cultural-cognitive pillar of the carbon market. Section 7 concludes by suggesting that since organizations play an active role in building institutions like carbon markets, these institutions can only become as strong, and as deeply embedded, as the organizations that construct them.

\section{Institutional Theory and Market Organizations}

\subsection{The Nature of Market Institutions}

Crises, whether financial or climatic force a reconsideration of the role of markets in structuring economy. Sociologists have considerably adjusted our understanding of the nature and function of markets. Katerina Knorr-Centina and Alex Preda (2005) explore the network of financial markets and suggest that the market is relational and socially embedded. Donald MacKenzie (2006) argues that economics is performative and that markets are performed by market actors. In Material Markets, MacKenzie (2009) explores how human nature, design and technology affect the development and shape of markets. These approaches suggest that markets do not exist a priori the individuals and networks that operate them. In questioning the relationship between economics and economy, Michel Callon (1998) comes to the conclusion that the market is neither a place nor a thing, but rather a system of organizing economy or an institution of capitalism. Using the case of carbon markets, this paper seeks to build upon sociological understandings to analyze how the market institution is constructed. To do this the article draws insight directly from institutional theory.

While we talk about 'institutional theory,' the approach is hardly monolithic. A significant cleavage within the field occurs between the work of early institutionalists and sociologists - Veblen, Weber, Durkheim, Polanyi — and modern neoclassical economists (Scott, 2001). The approach offered by the early institutionalists differs from that adopted by their mainstream neoclassical colleagues in four important respects: 1) early institutionalists claim pervasive market power and indeterminacy even under competition whereas neoclassical models assume perfect competition and determinacy through unique equilibriums; 2) endogeneity versus exogeneity of individual preferences and interests; 3) pragmatic and psychologically realistic models of economic behavior versus utilitarian assumptions regarding human behavior; 4) historical and geographic versus a-historic and non-geographic conceptions of the economy (Jacoby, 1990). Despite these differences, room for dialogue exists in understanding ideology and ideological change (Rutherford, 1995). In both of the approaches, institutions are broadly defined as a system of norms that regulate the relations of individuals to each other as well as what these relations should look like (Parsons, [1934] 1990). Institutions are embedded in socioeconomic and political context and by definition are the more enduring features of social life, giving solidity to social systems across time and space (Martin, 1994; Giddens, 1984). However, institutions constantly interact with society and are subject to change (Tolbert \& Zucker, 1996).

Knox-Hayes 3 
The demand side view of institutional formation argues that institutions come into existence to address social problems that arise. Some scholars, however, propose that institutional creation is also driven by supply-side processes (Meyer, 1994). Actors-such as those in the sciences and professions-occupy institutionalized roles that enable and encourage them to perpetuate and devise new rules and routines. They engage in and drive forward the project of 'rationalization,' whereby more and more areas of social life are brought under the rubric of institutions. Mimicry and adaptation also play an important role in the transfer of institutions from one region to another, particularly in the transfer of financial structures from developed to developing countries (Weber et al., Forthcoming 2009). Both supply and demand side views acknowledge that institutions are social constructs. Institutional change is shaped by the 'lock-in' that comes from the symbiotic relationship between institutions and the organizations that evolve in response to institutional incentive structures (North, 1990). Organizations require both social legitimacy and material resources and technical information if they are to survive and thrive in their social environments (Scott et al., 2000). For this reason, the founding of similar types of organizations (schools, hospitals etc) tend to concentrate in particular historical periods (Stinchcombe, 1965).

Dimagio and Powell (1983) recognize that once a set of related organizations emerges, actors make these organizations increasingly similar (isomorphic) as they try to change them. Isomorphic pressures give rise to increased similarity in organizational fields because the diffusion of templates for organizing benefits conforming organizations by increasing their symbolic performance (Heugens \& Lander, 2009). As organizations strive to conform to the values of society they become institutionalized (Granovetter, 1985). Institutionalization of organizations reflects the organization's own distinctive history, but also the values of the societies in which it develops (Selznick, 1996). For example, the similarities in organizational structure of schools and hospitals reflect normative values about education and care for the sick of the societies that have developed them. When considered across an organizational field, the process of institutionalization is known as structuration (Giddens, 1979). Structuration increases the extent of interaction among organizations in a field and develops of mutual awareness among participants in a set of organizations that they are involved in a common enterprise (DiMaggio, 1982). The construction and structuration of institutions of economic exchange are furthermore tied to the construction of networks of relationships among individuals within organizations (Uzzi, 1999; Coase, 1937).

Institutional theory and structuration theory both contend that institutions and actions are inextricably linked and that the institutionalization of organizations is best understood as a dynamic, ongoing process. While this work adds considerable insight to the understanding of organizations, institutionalists have pursued an empirical agenda that has largely ignored how institutions are created, altered, and reproduced. Structuration theory, on the other hand, largely remains a process theory with considerable abstraction and few empirical studies. A fusion of the two approaches would enable institutional theory to significantly advance by developing a model of institutionalization as a structuration process (Barley \& Tolbert, 1997). The combination of these approaches has been achieved in the work of Richard Scott and Neil Fligstein, providing a framework for understanding how market institutions are created, altered and reproduced by processes and relationships between organizations. 


\subsection{The Pillars and Carriers of Market Institutions}

In his book Institutions and Organizations, Richard Scott (2001) asks and answers the question of what institutions are and how they arise. Institutions consist of both ideas and structures, which develop common understandings and practices among communities. Common examples include marriage, professionalism, and adulthood. Three pillars underpin institutions: regulatory systems, normative systems and cultural-cognitive systems. The regulative pillar explains how institutions constrain and regularize behavior. Concerns include rule-setting, monitoring and sanctioning of activities. For example, in advanced industrial democracies governments always play a role in adjusting market operation and in setting the rules of function (Pierson, 1996; Dobbin, 1994). The normative pillar introduces a prescriptive, evaluative, and obligatory dimension to social life, and includes both the common values (what is desirable) and norms (how things should be done). Finally, the cultural-cognitive pillar is concerned with the shared conceptions that constitute the nature of social reality and the symbols and framing that create meaning.

These pillars give institutions stability, but only to the extent that they are perpetuated by people and other types of carriers, including symbolic systems (values, e.g. rule of law, democracy), relational systems (e.g. organizational hierarchy), routines (e.g. timetables) and artifacts (i.e. technology) (Scott, 2001; Jepperson, 1991). Organizations embody these four types of carriers of institutions. To survive they require legitimacy, which is attained either by institutionalizing the organization's regulatory, normative and cultural-cognitive conceptions or by altering these conceptions in line with existing institutions. Organizations arise and gain prominence by pursuing the distinctive cultural logics which are systematically codified in the institutions of a society. For example, firms seek profit, because one of the logics of the institution of capitalist societies is economic growth. Scott's conception of institutions shares Foucault's analysis of systematic power (Foucault, 2001). Institutions construct the frameworks and rules of control, and organizations attain power and legitimacy by conforming to these institutions.

Much of Scott's work looks at how organizations become institutionalized, and how organizations perpetuate and diffuse institutions (Scott, 2001). However, organizations also develop institutions. Treating market systems as institutions of capitalism, and using Scott's three-pillar framework, it is possible to investigate how organizations create the regulative, normative and cultural-cognitive aspects of the market institution. In order to do so, however, a brief discussion of the nature of the market institution is in order.

Markets are institutions which allow socio-economic organization; the dynamism of market societies is made possible by social organization. Sociologists, notably Karl Marx, Max Weber, and Emile Durkheim, have long recognized that the modern market economy is an outcome of deeper social processes that drive modernity (Weber, 1968; Durkheim, 1933; Marx, 1930). ${ }^{\text {iv }}$ Karl Polanyi and other early institutionalists built on this understanding to theorize how markets become the dominant organizational form of structuring material production (Polanyi, 1944). The premise of both approaches is that modern capitalistic societies use markets to reproduce their structure and material production. Neil Fligstein expands upon work within sociology to generate a systematic theory about the institutional structures necessary for market organization (Fligstein, 2001).

Fligstein uses a political-cultural approach to explain which social rules must exist for markets to function and what types of social structures are necessary to produce stable markets. The key to the approach is that social action takes place among fields of actors who try to 
dominate the field by producing a local culture (norms of behavior) that defines the social relationships between actors in a way that is beneficial to the definers (Scott \& Meyer, 1994; Bourdieu \& Wacquant, 1992; Bourdieu, 1977). The approach importantly understands the public and private nature of dominance operation and contestation. Public institutions such as regulatory agencies set the property rights, governance structures, and rules of exchange. Private institutions such as banks and exchanges set the conventions and instruments through which exchange takes place. For Fligstein, the key to understanding the institutional nature of market operation is market stability.

On the one hand, stability creates the political and social investment conditions allowing economies to produce. On the other, stability marks how firms establish dominance in reproducing themselves. As such, there is a balance of power between government officials, capitalists and workers in configuring the rules and institutions of a market (Geertz, 1983). Those who can establish stability, and consequently influence the rules of the market, are apt to make more gains. Importantly, Fligstein's political-cultural approach notes that achieving a stability is about creating legitimacy among the full range of market participants including regulators, buyers, and sellers (Fligstein, 2001). The notion of creating legitimacy recognizes that in exchanging commodities markets also communicate a variety of social relations (Fine \& Lapavitsas, 2000). Markets are a form of politics, and in particular the construction of property rights shapes political control (Fligstein, 1996; Campbell \& Lindberg, 1990).

Stability in a market system is built from the development of a normalized convention or dominant coalition among market actors, which includes the full range of social actors in capitalistic society (Knox-Hayes, 2009; Fligstein \& Stone Sweet, 2002). Fligstein highlights four types of rules relevant to producing the social structures that stabilize markets: property rights, rules of exchange, governance structures and conceptions of control. Conceptions of control, like conventions, are cognitive understandings of the social-organizational relationships among market organizations and firms. These understandings structure perceptions of how a particular market works. A large part of the balance of power in markets is determined by who builds and controls these four market structures.

Most of the rules and conventions governing markets are historical products. However, globalization is changing the very nature of markets and market economies (Barry \& Slater, 2002). As Fligstein himself notes, the political-cultural approach,-with its emphasis on market stability and conflict between incumbents and challengers - struggles to contend with the fluidity and dynamism of firms operating in a digital world. The explosion of information technology that occurred at the end of the 20th century has created a whole new set of markets, which are transforming the world in which we live (MacKenzie, 2009b; Castells, 1996). The shortcomings of the approach are particularly pertinent for carbon markets which are completely constructed for regulatory purposes within the technological revolution of the $21^{\text {st }}$ century. However, the political-cultural approach remains useful; carbon markets are still institutions which control social productivity requiring rules and conventions to operate (Knox-Hayes, 2008). To understand how these markets are developed it is important to understand the nature of these rules and conventions and how they are constructed.

\section{Framework and Methodology}

Despite the changing nature of markets, they remain institutions built upon Scott's regulative, normative, and cultural cognitive pillars. These pillars provide a continuum moving from the from the legally enforced to the socially assumed that shapes the operation of 
organizations (Hoffman, 2001). In turn these organizations embody the carriers of the institutions. Both Scott and Fligstein describe the relationships between organizations and institutions of functional $19^{\text {th }}$ and $20^{\text {th }}$ century markets as dialectic. The question under consideration here is what is the relationship between organizations and market institutions when those institutions are being constructed? In particular, how do incumbent and challenging firms construct the institutions of $21^{\text {st }}$ century carbon markets? Earlier work has explored how the financial centers of carbon markets are constructed through complementarity of incumbent and challenger firms (Knox-Hayes, Forthcoming 2009), but the role of organizations in institutional construction under modern conditions remains largely unexplored.

This article seeks to address this lacuna by examining the role of organizations in the construction of the social institution of carbon markets in Europe and the United States. Reversing Scott's framework, I argue that organizations play a critical role in establishing the carbon market institution. Given the number of market systems in operation-European Union Emissions Trading Scheme (EU ETS), U.S. Regional Greenhouse Gas Initiative (RGGI), California’s AB 32, U.S. Midwestern Climate Alliance, Canadian counterparties, and the \$330 million voluntary market (Hamilton et al., 2008)—-the question becomes which 'carbon market'? Here I refer to carbon markets as the social institution, as the idea and practice that carbon emission reductions can be packaged, traded and sold to mitigate climate change. The analysis here focuses on how organizations construct the regulative, normative and cultural pillars of the carbon market institution. Combining Scott's four carriers with Fligstein's four social structures, the analysis will consider the property rights, conceptions of control, relational systems and symbolic systems that organizations develop to carry the markets (Figure 1). Interviews with experts from legislatures, NGOs, industry associations, utilities, legal firms and think tanks are used to construct the analysis of the role of organizations in shaping market institutions.

[Insert Figure 1 about here]

Each interview has been qualitatively cross-checked with other interviews to verify the findings. The case study approach is well suited to describe and conceptualize the developing carbon markets and their relationships in space and time (Quattrone, 2006). As with all methodologies, it has drawbacks. In particular, perspectives and experiences of individuals are not always accurate representations of actions or facts (Berry, 2003). However, the triangulation of results confers rigor and credibility to the conceptualization (Strauss \& Corbin, 1998). A key prerequisite for this rigor is access, as only the testimony of key market makers and decision makers will afford an acceptable level of confidence in the findings (Goldstein, 2003). In this study institutional analysis is assembled through over 100 interviews with experts from the institutions (banks, brokerages, intermediaries, legal firms, consultancies, and wire services) constructing markets in London, New York, Chicago, Washington D.C. San Francisco, Los Angles and Paris. Owing to the sensitive nature of the issues under discussion, all interlocutors are anonymous (Appendix 1).

Interviews were conducted using a semi-structured format with an initial list of 19 questions. Information regarding the structure of the policy field and role of institutions was drawn from several standard interview questions including: What is (has been) the role of your institution in developing carbon markets? Who are your primary clients? Are there any relationships between your institution and regulatory agencies that are developing the carbon market? Are there any particularly important relationships between your institution and other organizations, in the U.S. and overseas? What do you see as the importance of legal expertise in developing the carbon market? What do you see as the importance of financial expertise? What 
sort of carbon products is your institution developing or using? Is there a carbon market culture, if so how would you describe it and how does it differ from other market cultures? Although the interviews were semi-structured, interlocutors were allowed and encouraged to explore other topics they felt relevant to their carbon related activities.

The standard interview format targeted one hour, but the interview length varied between 45 minutes and 2 hours depending on participant availability and interest. Detailed notes were taken during the interview. The transcripts were later formatted and uploaded to a data file using NVivo, a software package which assists with data queries and dialogue searches of coded text. Each interview transcript was labeled with the type of institution and position of individual interviewed. Relevant questions were coded into separate nodes, which allowed for the question responses to be grouped (yet remain distinguished with an institution/position label) and analyzed across institution type. The responses were triangulated within and across institution type. While these methods are qualitative, they were rigorously applied and could be replicated in other studies.

\section{Constructing the Regulative Pillar}

The carbon market institution is designed to govern behaviors which emit greenhouse gas emissions. Since these emissions are generated by virtually every country and industry, the size and impact of the market institution needed to mitigate them is considerable. The regulative component of a market is particularly important, providing the most solid testament of the existence of the institution. Governance systems and property rights both carry the carbon market institution. A number of policy makers, regulators, and partners in firms in London, New York, Chicago and Washington D.C. were interviewed to understand the role these firms play in developing the carbon markets and in particular in developing carbon trading rights and contracts (see Appendix 1 for a complete list of interviewees).

In constructing the regulative pillar of the carbon market, establishing scarcity (placing social value on carbon reductions through pricing) is of critical importance. While establishing the scarcity is in principle the purview of government and regulatory bodies, legal firms are often hired by the governments to help conduct this work. One of the partners interviewed indicated that they had worked with the European Commission to develop and EU ETS the trading system and the registries.

[Our partners] were involved in Kyoto discussion groups, and conferences, operating internationally, because they understood the potential of the market mechanism. There wasn't anyone else taking interest in this area. [Managing Partner] was transacting, developing partnerships around the world and he was based in a country that had not even yet ratified Kyoto...[Our partners] were working together as a small team and making a lot of noise, with policy makers, and law makers. They did a lot of work to make connections with the European Commission and for the EUETS. They were even involved in drafting the registry legislation. As well they got involved with contracts business from the early movers. - Partner, Legal Firm July 3, 2008, London

This interlocutor emphasizes how large an early effort these partners were taking because they believed in or were interested in developing emissions markets. He also notes that the firm actively played a role in developing the legislation. The legislation initiates the market by creating demand for carbon emission reductions. However, the regulation is in reality a reflection of an underlying social demand to address climate change. As a result, the demand for carbon credits can spread without regulation. For the EU ETS, regulative development of a 
price signal for carbon reduction was an important initial step in developing the carbon market. In the United States the market began to take shape before the regulation could form. As the growing voluntary market demonstrates, once a price signal is established for carbon (through regulation) in one geography, demand arises in other unregulated geographies. This is why there is a growing market to reduce emissions through offsetting (applied to flights, consumer goods, etc) even in unregulated areas by unregulated parties.

The main carrier of the regulative pillar is therefore not the regulation that caps emissions, but the property rights. Property rights allow individuals to form expectations which can be can reasonably held in dealing with others (Demsetz, 1967). Once the property right has been established and legally regulated, markets can begin to operate because they have something that can be bought, sold and otherwise traded. For carbon credits, constructing the property right is challenging because there is not a tangible underlying to the carbon credit; the credit marks the absence of emissions (Knox-Hayes, 2008). In part because of this irregularity, governments do not directly establish property rights for carbon reductions; legislation (like that establishing the EU ETS) only specifies that greenhouse gases will be capped, and that permits or credits will exist and would be tradable. The legislation does not necessarily specify what, if any, property rights will be held by the credit. Yet an ownership right is required to trade. As one legal expert explains:

The legislation determines the amount that is allocated and regulates and allocates EU allowances and RGGI allowances. In the environmental law literature and among environmental lawyers, emissions assets are not seen as real property rights; they are not acknowledged. If we don't create a right or title we can't buy or sell these credits. There is a Latin saying: Nemo dat quod non habet. What you do not have, you cannot sell. So in order to have any contract buying, selling or holding, there has to be a property right. We establish an ownership right that is specified in contract through the movement from one account to another. —Partner, Legal Firm, May 8, 2008 New York.

One of the reasons legislation does not do this, particularly in the United States under trading systems like the RGGI, is that the number of credits decreases over time. If governments distribute credits as property rights, then when they ratchet them down, they could be held legally responsible for taking property without giving just compensation:

RGGI doesn't use property right interests because when they ratchet down they will limit allowances. So they don't want a "takings claim": which is constitutional law, the US government cannot take property without just compensation. So federal communications broadcast licenses. The license holder doesn't have a property right, but if another company wants to buy them, what is their value? The value of the license has to be transferable. They are not tangible commodities so much as a limited permitted right to emit. That is the manifestation of the right, a chain of title makes it concrete by recording it in the chain of custody. That is why we are such a big part of the whole market. We are properly shepherding the right. The right itself is derived not just from contract, but from common law principles of jurisprudence through to principles of possession. - Partner, Legal Firm, Chicago, May 22, 2008

The allowance is a right to emit; it does not become a property right until it is traded. This is either done over the counter (matching buyer to seller) through contract, or through an exchange in partnership with a registry. In most cases, the property right, what many lawyers refer to as ownership title, is established by legal firms under existing legal structure. The primary method for doing this is to establish the legal certificates that house carbon reductions, but also to create contracts of trading and selling. The primary method of trading emissions reductions is through Emissions Reduction Purchase Agreements (ERPA). Drafted by lawyers, 
ERPAs include provisions relating to payment, delivery format and date, tax representations, basic corporate representations, basic covenants, and events of default and termination. Until trade becomes standardized these can take months to negotiate. To trade other financial products, the International Swaps and Derivatives Association (ISDA) developed the ISDA Master Agreement. Similarly, the International Emissions Trading Association has developed a Master Agreement to trade EU allowances. Standard contracts are also used by exchanges to trade more quickly. Some of the voluntary exchanges require traders to provide a statement of sole claim to ownership. For example, for offsets which were produced through a chain of companies, each company must sign a letter that they do not claim the right of the emission reduction.

As demonstrated by the mimicry of the ISDA Master Agreement, legal firms structure contracts by borrowing and adapting expertise from different areas in the firm (Knox-Hayes, Forthcoming 2009). The contracts to trade carbon are adapted from contracts to trade other commodities and financial derivatives. A number of other legal issues firms address, such as taxation issues in moving credits across jurisdictions and acquisition issues in establishing emissions reductions projects, are likewise built from borrowed expertise. In establishing legal precedent for the property rights as well as for the other aspects of legal transfer and operation, the legal firms thereby help to construct the regulative pillar of the carbon market institution. The legal firm constructs the (new) carbon market institution by copying (old) social institutions of which it is itself is a product.

In particular for carbon markets, a number of different specialties combine to construct climate law. One of the market leaders for carbon work is Baker and McKenzie. Their practice of climate law_combining a range of legal disciplines, including public international law, commercial law, finance and financial markets, international and national environmental law, and tax law-exemplifies the transfer of existing institutional perspectives, through organizations, to the newly formed institution. In addition to establishing a number of the contracts in developing markets the firm has developed the CDM rulebook (Baker McKenzie, 2009). The rulebook does not change any of the legislation or regulations governing the operation of the Clean Development Mechanism. Rather, it organizes this information in a way that is understandable within a legal framework, providing a service that makes the markets more accessible and easy to operate for participants. By helping to establish the regulative pillar of the carbon market, Baker and McKenzie asserts its authority and expertise in determining carbon legal function and practice and ingrains its importance in the function of the market institution.

Even with defined contracts and legal practice, carbon credits still lack physical substance. Another important organization that works with legal firms to develop the regulative pillar or the institutional carrier of the property right is the registry. Registries track the lifecycle, including creation, trade, and expiry of the carbon credit. They also play an important role in standardizing the structure and function of contracts. As the following interlocutor highlights, it is not necessary to trade through a registry, particularly in voluntary markets. However, consumers and investors start to demand the standardization and quality control that a registry provides.

In the voluntary market there are lots of different standards. The voluntary markets are now demanding rules. You can trade without one [a registry], but people are now demanding that there is a registry. That starts the demand for better standards. Demand for quality, consistency, etc. is driving demand for standards. The demands of the financial markets and investors is benefiting and driving the rules. There is no policy in the voluntary markets; the standards come from trying to develop a more effective and 
efficient market and from social demand without policy, but the voluntary market is not vibrant. How do you make it viable? It is small compared the EU ETS. That's where you see the power of policy; it creates a much larger, more vibrant and liquid market.—Partner, Legal Firm May 8, 2008 New York

Registries and standards organizations play an important role in building a consistent regulatory pillar to the market mechanism, standardizing legal contracts and products over time. A number of these organizations have evolved to provide quality control for the production of offsets, including the voluntary carbon standard and the gold standard. Without specification from regulatory bodies regarding accounting practice, stand-alone standards have been established. For example the Greenhouse Gas Protocol, a partnership of the World Resources Institute and the World Business Council For Sustainable Development has produced the corporate and project based accounting standards used by most trading systems, registries, and private organizations (GHGP, 2009). Although carbon markets require government initiation and intervention, it is these organizations in conjunction with legal firms that construct the primary carrier and governance systems of the regulative pillar.

\section{Constructing the Normative Pillar}

Compared to the regulative pillar, the normative pillar of an institution is fairly intangible. There is nevertheless a social force supporting the existence of the institution, recognition that the institution fulfills some positive social role. Social beliefs and symbolic systems generate and carry the normative pillar. For carbon markets, the normative pillar reflects the social value of the market institution and its ability to provide a social good by addressing climate change. The moral component of the market directly links with the power to drive innovation (Elam \& Arrow, 1993). The price signal is a recognition of social value of reducing emissions, which then becomes translated into low-carbon technology development. However, this value cannot be taken for granted; it must be constructed. The recognition of the problem and the solution does not automatically or naturally exist among the public or corporations. Awareness of both the problem and the value of the solution must be constructed and disseminated (Bansal \& Howard, 1997). Here, as Michel Callon suggests, there is an undeniable link between the conduct of scientific research and the organization of economic markets (Barry \& Slater, 2002).

The normative pillar of the carbon market institution is butyl first through scientific organizations and the media which disseminate the science and create awareness for the problem. The value of the carbon market institution as the solution to mitigate must then be constructed. This is done in large part by financial institutions which demonstrate the price signal, or social value, of reducing greenhouse gas emissions. In organizations, there is a delicate mixture of both organizational value and individual concern creating awareness and response to the environmental issue (Bansal, 2003). The price signal and awareness of the problem of climate change are the principal symbolic carriers of the market institution.

\subsection{Acknowledging and Disseminating the Scientific Evaluation}

While scientific knowledge about the impacts of climate change has been growing for some time, public awareness has been far more uneven. In Europe, public awareness of the issue built far more steadily than in the United States, where there was a strong public campaign to deny the science behind climate change, particularly among corporations after the Bush withdrawal from the Kyoto protocol (Levy \& Egan, 2003). At the same time there has been a 
growing campaign by scientific organizations, NGOs, and public activists to create awareness for the science behind climate change. As one interlocutor explains from a large scientific advocacy organization:

\begin{abstract}
We realized we had to educate and motivate the United States. There was a public disinformation campaign suggesting that climate change was not happening, not human-induced. Our role has been to waken people to the science and facts, to the edge of scientific knowledge. We have worked with scientists on staff, academics and agency scientists on impacts reports. These are important for driving the spotlight. We got American authors from the IPCC for Congressional testimony. We also asked our scientist members to talk about the IPCC in the media. We did this in the timeframe when the Federal government was not fulfilling its mission. We started in 2001, and now we say that federal agencies and local agencies should be doing this. Things started to change on a federal landscape in 2007. Things also palpably changed with the Inconvenient Truth. —Climate Scientist, Scientific NGO, Washington D.C., September 8, 2008.
\end{abstract}

The construction of collective acknowledgement regarding climate change does not necessarily mean support for a carbon market. Most of the experts in NGOs and scientific organizations said that they avoid prescribing possible solutions when educating the public:

\begin{abstract}
The work we do is intended be policy relevant but not prescriptive. We provide a scientific basis for understanding climate change. We provide communication and education, and ongoing provision of new findings, which is the public relations aspect of science. Education is both formal as education in school systems and informal as in a variety of media including museums and aquaria websites. Education provides receptivity to communication. It could potentially play a major role. We have briefed publicly and privately to Congress and to the Administration. The science is unequivocal about certain aspects of the warming. The work of this program has a voice. It is a strong voice and it is essential to transform scientific information into general information. - Director, National Climate Science Program,
\end{abstract}

Washington D.C., September 16, 2009

In educating the public, even in a policy-neutral manner, these organizations construct an important component of the normative pillar of the market. The carbon market institution needs a community belief in its purpose to be successful. The recognition that climate change is real and anthropogenic is an important factor underlying the credibility of the institution.

The efforts of organizations that disseminate science to government agencies and public advocates such as Al Gore have had some success in generating public awareness of climate change. Many of the individuals interviewed suggested that there had been a palpable shift in awareness of the climate change problem in the United States starting around 2006. In addition to educational campaigns, they cited a number of factors that have contributed to growing public awareness, including Hurricane Katrina, Al Gore's award winning film, and the Intergovernmental Panel on Climate Change (IPCC) scientific assessments. Broad collective acceptance of the normative need for a solution to climate change is critical to efforts to develop the regulative pillar of the market (Knox-Hayes, 2009).

Finally the normative pillar, the symbolism of the carbon markets, can be seems through the perspectives of those who work in the market. The majority of the individuals interviewed explicitly claimed a positive normative benefit to working in these markets. A number of these individuals suggested that there was something physically tangible about the markets:

It has a general interest because it is preventing a major environmental catastrophe. Climate change is a big issue, worthwhile in general level of broader interests, it gives purpose to what I am doing. I am not a green activist, just a realist about what can be achieved and I have an interest in what can be a new area of law, using this mechanism to bring about environmental objectives, which is more acceptable to business. 
It is an exciting area of law: it is intrinsically interesting, tangible as a subject, it has a point, and it is real. It involves projects and emissions. It is not just a dry tax issue. Not that I mean to criticize other areas of law, which I know are important. But this is easier to see and to understand, it is providing interest.

—-Partner in a Legal Firm, London, July 3, 2008.

The work, particularly when viewed from a financial or legal perspective, is easily connected to something that has a real impact and which makes a difference in the world. Additionally, a number of individuals spoke about their children and the belief that working in the carbon markets would give their children a better future:

When my 2 daughters came along I became interested in protecting the environment. I am concerned about the future of the world my children will live in. You become jaded on Wall Street. I wanted to do something good, but still use my finance background. It is positive and not just about making money; I wanted to do something like this. I reach out to Wall Street. - Senior Finance Fellow, Environmental Action Group, May 16, 2008, New York

The normative aspect of the market institutions is seen by this type of response directly inside of the market organization. Market participants view the market as something that contributes to the betterment of society. This symbolism is also more broadly recognized in the social value attributed to carbon mitigation through the market. In a tangible way, the value can be seen through the price signal attached to carbon reductions.

\subsection{Recognizing the Social Value with a Price Signal}

Outside of the direct market system, recognition of the existence of the price signal for carbon and the response of carbon market actors also indicates the social value of addressing climate change. A legislated market does not automatically begin to operate. Market actors must demonstrate the carbon market potential, using early demonstration trades to build the price signal by showing that the market could work. While the existence of a price signals social value, the difficulty of establishing a price for something that has no physical underlying cannot be overestimated. A price requires social or shared demand for a good and an act of agreement between two or more parties. This process is all the more difficult when the parties that will trade a good are doing so under obligation. This is in essence the nature of carbon markets. Legislation established the existence of the carbon goods and the ability to trade them, but it establish demand or the knowledge of how to trade. This aspect of normalizing the markets must be done by financial organizations.

The price signal was built in phases. In the first instance, it was not compliance parties, but financial and development organizations that established the price signal to demonstrate the ability to trade. Trading an artificial commodity is not automatic; compliance parties have to be taught how to trade.

The first deal was done in 2003 between [investment bank] and [energy firm]. It was a PR deal. We had a vision; we will put a mark out there, will do a deal and kick off a market. In 2003 [energy firm] bought 5000 tonnes from [investment bank] (forward contract) in whatever form it comes in. This was a bilateral deal. We did another deal in 2004 between a Slovakian counterparty and [energy firm], 25\% for 100,000 tonnes, we settled at 5 Euro. This was our first bigger deal. We had regulatory expertise and we believed something was coming. A deal in June and July, a deal a month maximum, this is how the market came about. It was not so much a matter of financial sophistication but of knowing what kind of things to write into contracts, the legal expertise to write contracts. The financial sophistication followed after. Director, European Financial Exchange, New York, October 30, 2007. 
Banks and development organizations initiated the market. They started constructing deals to buy and sell carbon between counter parties to demonstrate the potential of the market. These types of organizations also provided financing for the market. For example, development banks and organizations began to develop carbon funds, which could provide credit to the fledgling market by financing early trades and investments in emissions reduction projects.

In 1997 we developed carbon fund. There was very little of the market. You have the concept of the Kyoto protocol, and some language, and that's it. You can have the full concept, but [among compliance parties] there is just a lot of skepticism and resistance. The role that [our institution] played was A) to develop the [a carbon fund]. A number of companies could have done it but it was important that the [our institution] did it because it has member governments around the world. B) Through the funds we brought in governments and companies that now have a stake in the market. - Director, Intergovernmental Development Organization, September 12, 2008 Washington D.C.

Once the potential of these trades were demonstrated, other financial organizations (i.e. investment banks) joined in, regularizing and operationalizing the market. Exchanges then came forward to help regulate the flow and demand of the market. A similar process unfolded for the finance of projects to reduce emissions under the Clean Development Mechanism. In 2004 the premier buyer was the World Bank, which established early carbon funds. In 2005 government funds entered the market, followed by boutique banks and corporations. The last wave of movers into the market was hedge funds and investment banks (Figure 2). With each new entrant, the size of finance and capital circulating through the markets grew, and the price signal strengthened.

\section{[Insert Figure 2 Here]}

Financial organizations play a critical role in developing the normative pillar of the market, establishing and propagating the price signal. For example, in addition to the growing voluntary market, private initiatives have arisen such as the Carbon Disclosure Project (CDP) and the Carbon Principles. The United Kingdom-based CDP works with large investors and shareholders to encourage corporate disclosure of greenhouse gas emissions. The CDP represents 475 institutional investors accounting for \$55 trillion under management. In 2008, the CDP published emissions data for 1550 of the world's largest corporations, amounting to 26\% of global anthropogenic emissions. Mirrored after the Equator Principles, the Carbon Principles are guidelines to assess the greenhouse gas risks in financing electric power projects. The principles were developed by three leading Wall Street banks_-Citigroup Inc., JP Morgan Chase, and Morgan Stanley - in consultation with the Natural Resource Defense Council and the Environmental Defense Fund. The Carbon Principles provide a consistent approach for banks and their U.S. power clients to evaluate and address carbon risks, energy efficiency, and technology use in the financing of electric power projects. Initiatives such as these use the price signal of carbon to spread awareness of the social value of reducing carbon emissions. They extend the impact of the price signal to a wider group of investors, corporations and consumers, raising the collective normative awareness of the impacts of the market.

As the symbolism of addressing climate change suggests, the pillars of the market institution are connected. The existence of the normative pillar drives the development of the regulatory pillar. Once the social value behind the carbon market is demonstrated in one area through the price signal, demand for the operation of the market can be moved to another area. 
This can be seen in the way the regulatory creation of the market Europe first created a strong price signal, which spread voluntary markets and regional schemes into unregulated areas like North America, Australia, Asia and Russia. The normative aspects of the market institution can reach beyond regulated jurisdictions.

\section{Constructing the Cultural-Cognitive Pillar}

Relational systems and conceptions of control carry the cultural-cognitive pillar of the market institution. These are particularly important for markets, which require interlinking components - banks, legal firms, exchanges - to operate. Another aspect of the culturalcognitive pillar is a sense of community and understanding of organizational place within the community. The carbon markets are so new that the traditions and expectations of behavior are not established. The organizations that operate carbon markets seek to establish a system of relationships and conceptions of control, structuring the market and carrying its culturalcognitive aspects.

\subsection{Relational Systems}

Since carbon markets are new, the relationships that enable the market to operate, such as client-service provider relationships and chains of services, must be built. Market conferenceshosted by consultancies and similar organizations_-build the relational component of the carbon market. Two of the largest are the Point Carbon and Carbon Expo conferences, which are held in London, New York, Copenhagen and Munich every year. These conferences allow market participants to develop relationships and build communities:

Conferences are crucial to establishing these relationships as well. A lot of business comes out of them. At the moment it is a small universe, people know each other. The market network has its own unique culture. It is different from the energy market. The oil and gas market is a lot of fat white guys in conference rooms. They are well established and set in their ways. The carbon culture is much more dynamic. There are a lot of young people, women, tri-athletes, and vegetarians. It is an exciting dynamic community. People are not wearing suits. It raises the interesting question of which comes first the culture of the market or the people in it. Will the carbon markets culture stay this way? Does it reflect the time epoch in which it is constructed? - Carbon originator at an investment bank, New York, October 26, 2007

The relationships established at carbon market conferences are important for building trust and credibility in the institution. They also construct common traditions, routines of interaction and expectations:

We attended the carbon expositions in Cologne, in San Francisco, and Singapore. We put our name out and live by word-of-mouth as well. Some partners come to us through referral. It is something that develops on its own; people find us...right now carbon dioxide partnerships are more important because the traditions are not decided yet. So getting people on your side on your way of doing things is important. Partners need credibility; no one can build this market alone. It is a matter of do I trust what you are providing me. —Vice President, Global financial Services Institution, London, July 4, 2008.

The carbon market is a dynamic institution with complex operation required to meet its objective. To successfully address climate change, the carbon markets must organize not only the finance, but also the socio-economic productivity to transition energy sources. No single institution can build the carbon market. Although the market is about competition and profit, it is also a collaborative, cooperative effort. The organizations need to share expertise to build the 
market. Because the market is designed to address a problem with tremendous scale and scope, the culture of the market is likewise very broad. A number of the interlocutors commented on the diversity of the backgrounds of the individuals building the market:

People feel like part of international movement to make the world a better place. Wall Street types (who will make a lot of money out of this) are mixing with environmental groups. They are at dinners and events together even if they are not always on the same page. People feel like they are doing something good...It is a livelier market community than most. It is a more diverse and dynamic community. Individuals are younger, well traveled, energetic, aware, and then there also typical money makers. - Carbon originator at an investment bank, New York, October 26, 2007

The conferences allow participants to establish working relationships, exchange business and clients, and create new ideas.

London is where ideas happen and connections are made. It's where innovation occurs where the brainpower sits. It's not just a nice city with good tax rules, but a lot of smart people with the same goals are constantly processing against each other, creating ideas. —Vice President, Global financial Services Institution, London, July 4, 2008.

These relational systems are an important aspect of the cultural-cognitive pillar of the market. They would not be formed as easily, if at all, without the facilitation of organizations running the conferences. These conferences construct a common market culture through socialization, education, and training. The individuals who are participating in the carbon market recognize and identify with this culture.

\subsection{Conceptions of Control: The 800lb Gorilla and the Financial Capitol of Europe.}

The other important carriers of the cultural-cognitive pillar of the carbon market are conceptions of control. The relational systems provide the structure of the market; conceptions of control help to establish power structures among individuals, firms, and regions. Institutional theorists like Scott often focus on the conceptions of control between challengers and dominant firms in an industry. Incumbent and challenger firms compete to form carbon markets as well. However, what is more prominent in the carbon markets is the construction of region-based conceptions of control, particularly between the city centers of London and New York. Affiliation to the centers seems to contribute more to the culture of the markets than affiliation to particular firms.

Many of the individuals interviewed, particularly experts in senior-level positions, had moved frequently and fluidly between organizations. Moving between organizations did not seem to engender much animosity, but was rather viewed as an accepted norm an emerging industry or market where expertise was unique and highly sought after. In contrast geographic affiliation seemed significant. Individuals were particularly attached to their geography of residence. The individuals interviewed displayed a clear sense of the role of their financial center was in constructing the market. When asked about the relationship between the financial centers, most participants recognized the need for at least three major financial centers, New York, London and one in Asia. Indeed this is how the global economy operates with a seamless transition form one time zone to the next. Nevertheless, there was a sense of ownership and positioning. A number of individuals in New York and in Washington D.C. referred to Wall Street as the 800lb gorilla of the financial world: 
We are that much slower here, so it depends on the new President. Regulations are coming to the United States and at the federal level. Once the U.S. decides to do that and when it does, New York is the 800lb gorilla. -Vice President, Cleantech Finance Firm, Washington D.C. November 20, 2007

When asked about New York as the 800lb gorilla a number of traders and other financiers were confused about the term in London. It is a cultural construct. One consultant posited that if London were to have a symbol it would be the swan, "It is cool, powerful, graceful, elegant calm on the surface but ferociously pushing under the water." In agreement, several financiers in London referred suggested that London is the financial capitol of Europe.

London is already a major financial hub. It is perhaps the foremost financial hub. Whereas New York is the financial capitol of the United States, London is the financial capitol of Europe. London is very European. It is still a part of the U.K. but perhaps it is also a bit more arrogant than the rest of the U.K. —Associate, Global Professional Services Firm, London, December 3, 2007

Even though London is not physically a part of Europe, it is attached to Europe as a center for control of finance across the entire continent. By contrast, New York is 'merely' the financial capitol of the United States.

These conceptions of control are purely that, conceptions. However, they are important. There is considerable drive to construct an international carbon market particularly between the United States and Europe. If the carbon market reaches its full potential it will easily become a $\$ / € 1$ trillion market. Although the need for at least three major financial centers to manage spheres of influence and transfer between global time zones will not disappear, control over the operation of a trillion dollar/euro market will influence the balance of power (or conception of power) between these financial centers. Carbon markets will be important not only because of their size, but because of their undeniable link to energy and clean technology markets. In perpetuating conceptions of control, financial centers have a stake in determining how the market institutions operate. Organizations and individuals within the financial centers create these conceptions of control.

Whether they reflect reality, conceptions of control within firms or regions commit members to affiliation and to working to perpetuate established market structures and relationships. As such, conceptions of control are an important carrier in building the culturalcognitive pillar of the market. As the interlocutors highlight, there are already growing regionally specific carbon market cultures to which market participants affiliate. New York, particularly Wall Street, has a sense that it is the 800lb gorilla pushing its weight and its will around the financial world. London sees itself as a more sophisticated European citizen. Organizations in both financial centers are successfully bringing these established conceptions to the carbon markets, which imbue the carbon market institution with regional conceptions and cultures.

\section{Conclusion}

Scholars in the sociology of finance argue the market is more than just a system of exchange and does not exist $a$ priori the organizations and individuals that enact it (Knorr-Cetina \& Preda, 2005). The institution of the market is a network of common belief and practice that is shared and communicated by market actors (Callon, 1998). Benedict Anderson's concept of 'imagined communities' is a good analogy to understand the importance of institutional pillars of the market (Anderson, 1991). Most communities, especially on the scale of nation-states are 
imagined in the sense that the most of the members of the community never meet or associate in person. For example there are roughly 300 million Americans. Each individual may personally connect with a dozen or a hundred, and yet the 300 million define a common community with common institutions. Scott's three pillars denote the components required to bind together imagined communities under institutions of common practice and understanding.

This article has drawn on institutional theory to study the development of carbon markets as an institution giving individuals a common understanding and practice to address climate change. While institutional theory adds considerable insight into how institutions shape organizational structure and operation, the literature has (relatively) neglected the impact of organizations in shaping institutions. This article combines the work of Richard Scott and Neil Fligstein to produce a framework for understanding the shape and structure of market institutions. It contributes to the literature by exploring how organizations build a market institution, in this case a carbon market. The task of building the carbon market institution is all the more complex because carbon markets are being constructed from scratch and lack tangible goods for trade. The three pillars of the market institution are required to give it shape and meaning, which is carried through four primary carriers, property rights, symbolic systems, relational systems and conceptions of control.

Carbon markets are regulatory constructions. Unlike other market systems they do not arise initially from supply and demand. To succeed as an institution mitigating greenhouse gases, carbon markets require conscious construction of the social pillars and carriers. However, as this article has aimed to demonstrate, regulators cannot build these pillars. They are instead built from the transnational organizations that operationalized the markets. As a result, the strength of the institution cannot be determined by regulation alone. Certainly regulation gives the markets credibility, but their ability to become an institution of common practice relies on the strength and embeddedness of the organizations that build them. The market does not arise naturally out of supply and demand; it is a form of social network. It is not so much a thing as a system of action and practice. Success requires belief, trust, confidence, but also action. The individuals that were interviewed often referred to the labor or effort required to build the market. Most of this work was dedicated to building relationships, to building common frameworks of belief and practice and to incorporating additional members. Everything from the legislation to the infrastructure of the market is built through partnerships and coalitions, because there is a sense that something like a carbon market cannot be built alone. The interviews shed light on the social and collective nature of the endeavor and the institution itself; which is often unrealized. A carbon market is more than a place of trading reductions; it is a network of individuals, ideas and belief that pricing carbon and seeking alternative will address climate change.

The idea of market networks as an institution has not reached its full potential within economic theory. Through analysis of the development of carbon markets as systems designed to reduce greenhouse gas emissions, this article has sought to demonstrate that markets are transnational organizational networks communicating social value. The price signal is a form of value. The carbon market is artificial in the sense that its existence derives from regulation. Yet the demand to address climate change is real and tangible. Building the market institution is to a large extent a process of realizing demand that already exists, and communicating the social value of reducing emissions across industries and regions.

The scope and the scale of the climate change problem cannot be underestimated. The greenhouse gases that drive climate change are produced by virtually every sector of every 
society, implicating the daily activities of billions of people. The solution requires a coordinated response among billions. Ultimately, the goal of the carbon market institution is to spread the common belief and to organize a response among as large a collective as possible. Carbon markets are one of a range of options to reduce greenhouse gas emissions, including taxes and command and control energy transition measures. To be successful the markets must generate real reductions; they must ratchet down greenhouse gas emission production (MacKenzie, 2007). What this article has sought to demonstrate is that it is not so much a matter of markets versus government response versus public behavior change. Political will, public awareness, and market operation are all connected and all required to achieve low carbon economy. To be successful carbon markets must ultimately not reduce greenhouse gas emissions to zero; they must rather communicate the social value of reducing emissions to such an extent and scale that there is enough political will, public drive, and market awareness to transition energy sources.

The carbon markets are still fledglings. Their ability to communicate the social value of addressing climate change and to organize a collaborative response remains to be determined. This study provides only an early understanding of the structure of the market institution as well as how it is being built. Understanding the structure of the market institution as well as the organizations structuring it would benefit from inquiry over time. In particular, the impact of the current financial crisis on institutional development would provide an interesting line of inquiry into the impact of context in shaping an institution. The study is also limited in its geographic reach. The research should be expanded to other regions including Latin America and Asia. In particular the initiation of exchanges in India and China presents the opportunity to examine the impact of culture on the transfer of institution. For all intents and purposes carbon markets are a Western invention built by Western organizations. Yet, the response to combating climate change needs to be global, and the initiation of these markets has created a normalized response that will be difficult if not impossible to dislodge. How other cultures will deal with the normalization of the carbon market institution and the organizations that have developed it are interesting and valuable areas of investigation. 
Figure 1. Matrix of the three pillars and carriers that construct market institutions

\section{Three Pillars of Market Institutions}

\section{Market Carriers}

Regulative

Normative

Cultural-Cognitive
Property Rights

Symbolic Systems

Figure 2. History of CDM Buyers from (Saines, 2006)

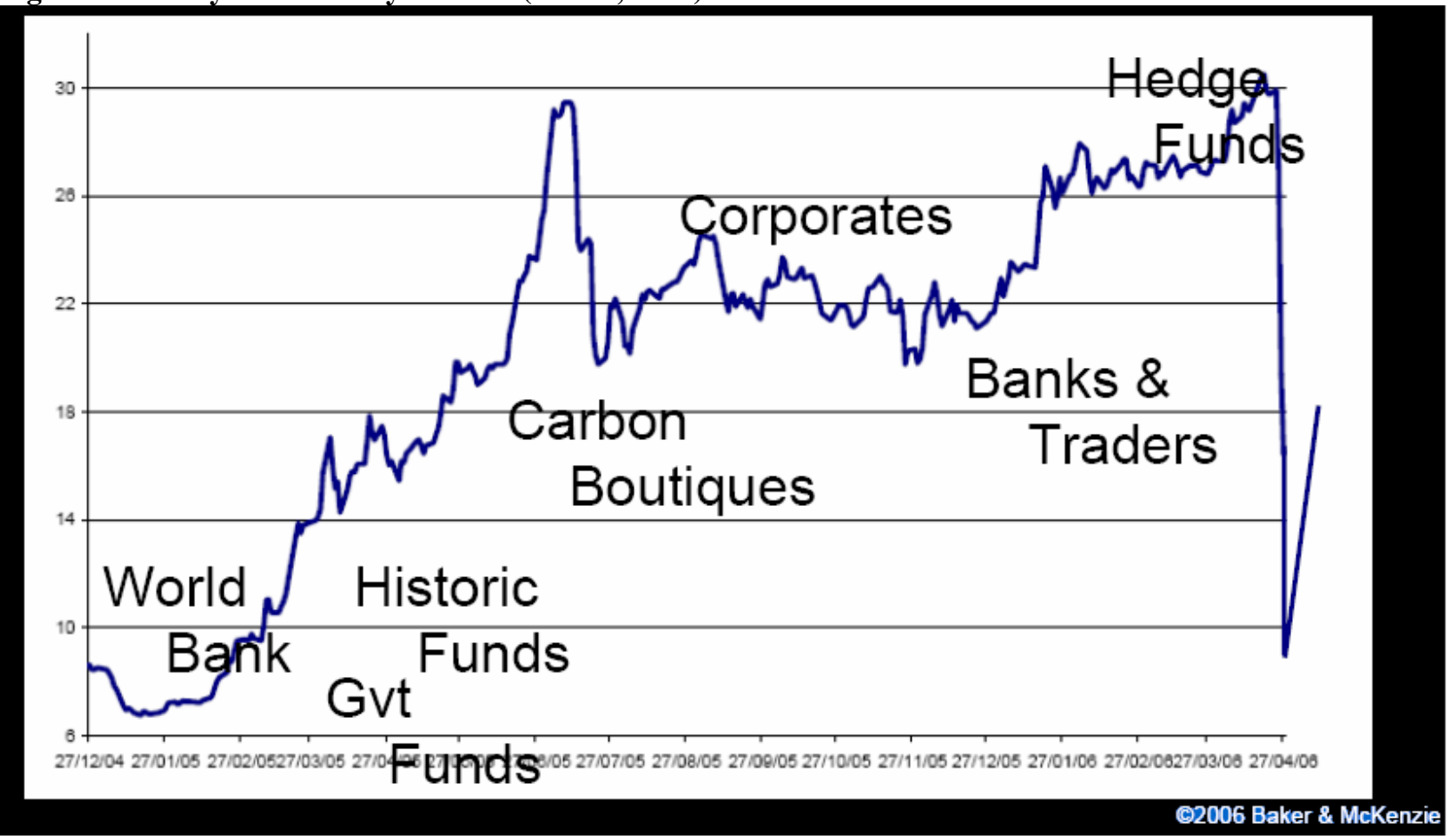




\section{Appendix 1. List of Interview Participants}

\begin{tabular}{|c|c|c|c|c|}
\hline $\begin{array}{l}\text { Interview } \\
\text { Number }\end{array}$ & Date & Organization Label & Interlocutor Position & $\begin{array}{l}\text { Interview } \\
\text { Location }\end{array}$ \\
\hline 1 & $9 / 14 / 2007$ & Investment Bank A & Carbon Originator & New York \\
\hline 2 & $10 / 20 / 2007$ & Exchange A & Commercial Director & New York \\
\hline 3 & $10 / 26 / 2007$ & Investment Bank A & Carbon Originator & New York \\
\hline 4 & $10 / 29 / 2007$ & Consultancy A & Chairman and Founder & New York \\
\hline 5 & $11 / 1 / 2007$ & News Wire A & Correspondent & New York \\
\hline 6 & $11 / 2 / 2007$ & Carbon Asset Developer A & $\begin{array}{l}\text { Country Director of U.S. } \\
\text { Operations }\end{array}$ & New York \\
\hline 7 & $11 / 2 / 2007$ & Hedge Fund A & Fund of funds manager & New York \\
\hline 8 & $11 / 5 / 2007$ & News Wire B & Publisher & New York \\
\hline 9 & $11 / 6 / 2007$ & Carbon Asset Developer B & $\begin{array}{l}\text { Director of Carbon Financial } \\
\text { Services }\end{array}$ & New York \\
\hline 10 & $11 / 6 / 2007$ & Investment Bank B & Carbon Sales Associate & New York \\
\hline 11 & $11 / 7 / 2007$ & Carbon Asset Developer B & $\begin{array}{l}\text { Vice President of Emissions } \\
\text { Reductions Projects }\end{array}$ & New York \\
\hline 12 & $11 / 7 / 2007$ & Investment Bank C & $\begin{array}{l}\text { Associate Director of } \\
\text { Institutional Equities }\end{array}$ & New York \\
\hline 13 & $11 / 7 / 2007$ & Investment Bank D & $\begin{array}{l}\text { Director, Office of the } \\
\text { Environment }\end{array}$ & New York \\
\hline 14 & $11 / 8 / 2007$ & Investment Bank E & $\begin{array}{l}\text { Director of Energy and } \\
\text { Environmental Market } \\
\text { Regulation }\end{array}$ & New York \\
\hline 15 & $11 / 8 / 2007$ & Exchange $\mathrm{B}$ & $\begin{array}{l}\text { Vice President, Institutional } \\
\text { Marketing }\end{array}$ & New York \\
\hline 16 & $11 / 9 / 2007$ & Hedge Fund B & Partner & New York \\
\hline 19 & $11 / 23 / 2007$ & Consultancy B & Director & London \\
\hline 20 & $11 / 23 / 2007$ & Cleantech Investment Firm & European Director & London \\
\hline 21 & $11 / 23 / 2007$ & Investment Bank F & $\begin{array}{l}\text { Vice President, Carbon } \\
\text { Emissions Originator }\end{array}$ & London \\
\hline 22 & $11 / 27 / 2007$ & Reinsurance Firm & $\begin{array}{l}\text { Managing Director, } \\
\text { Environmental Markets }\end{array}$ & London \\
\hline 23 & $11 / 28 / 2007$ & Investment Bank G & $\begin{array}{l}\text { Global Head of Carbon } \\
\text { Emissions }\end{array}$ & London \\
\hline 24 & $11 / 29 / 2007$ & Energy Organization & Executive Director & $\begin{array}{l}\text { Washington } \\
\text { D.C. (Phone) }\end{array}$ \\
\hline
\end{tabular}




\begin{tabular}{|c|c|c|c|c|}
\hline $\begin{array}{l}\text { Interview } \\
\text { Number }\end{array}$ & Date & Organization Label & Interlocutor Position & $\begin{array}{l}\text { Interview } \\
\text { Location }\end{array}$ \\
\hline 25 & $12 / 3 / 2007$ & Consultancy C & Head of Advisory Services & London \\
\hline 26 & $12 / 3 / 2007$ & $\begin{array}{l}\text { Global PSF/ Consultancy } \\
\text { D }\end{array}$ & Consultant & London \\
\hline 27 & $12 / 4 / 2007$ & $\begin{array}{l}\text { Boutique Investment Bank } \\
\mathrm{H}\end{array}$ & Associate in Advisory & London \\
\hline 28 & $12 / 4 / 2007$ & Investment Bank A & $\begin{array}{l}\text { Associate Investment } \\
\text { Banking }\end{array}$ & London \\
\hline 29 & $12 / 6 / 2007$ & Brokerage A & $\begin{array}{l}\text { Vice President of European } \\
\text { Environmental Markets }\end{array}$ & London \\
\hline 30 & $12 / 6 / 2007$ & Hedge Fund C & $\begin{array}{l}\text { Director, Global } \\
\text { Environmental Finance }\end{array}$ & London \\
\hline 31 & $12 / 6 / 2007$ & Investment Bank G & Carbon Trader & London \\
\hline 32 & $12 / 7 / 2007$ & Carbon Asset Developer C & $\begin{array}{l}\text { Head of Corporate } \\
\text { Communications }\end{array}$ & London \\
\hline 33 & $12 / 7 / 2007$ & Carbon Asset Developer C & Asset Marketer & London \\
\hline 34 & $12 / 7 / 2007$ & Carbon Asset Developer C & Resource Manager & London \\
\hline 35 & $12 / 7 / 2007$ & Legal Firm A & Associate & London \\
\hline 36 & $5 / 5 / 2008$ & Regulatory Agency A & Economist & New York \\
\hline 37 & $5 / 5 / 2008$ & $\begin{array}{l}\text { Environmental Think Tank } \\
\text { A }\end{array}$ & Senior Analyst & New York \\
\hline 38 & $5 / 6 / 2008$ & $\begin{array}{l}\text { Financial Services } \\
\text { Company A }\end{array}$ & $\begin{array}{l}\text { Manager, Technology and } \\
\text { Business Development }\end{array}$ & New York \\
\hline 39 & $5 / 7 / 2008$ & Legal Firm A & Partner & New York \\
\hline 40 & $5 / 7 / 2008$ & Legal Firm A & Associate, Europe & New York \\
\hline 41 & $5 / 7 / 2008$ & $\begin{array}{l}\text { Financial Services } \\
\text { Company B }\end{array}$ & $\begin{array}{l}\text { Managing Director, } \\
\text { Commodity Futures }\end{array}$ & New York \\
\hline 42 & $5 / 7 / 2008$ & $\begin{array}{l}\text { Financial Services } \\
\text { Company B }\end{array}$ & $\begin{array}{l}\text { Global Head, Commodity } \\
\text { Futures }\end{array}$ & New York \\
\hline 43 & $5 / 7 / 2008$ & $\begin{array}{l}\text { Financial Services } \\
\text { Company B }\end{array}$ & $\begin{array}{l}\text { Marketing, Commodity } \\
\text { Futures }\end{array}$ & New York \\
\hline 44 & $5 / 8 / 2008$ & Legal Firm B & Structured Finance Lawyer & New York \\
\hline 45 & $5 / 8 / 2008$ & Investment Bank D & Executive Director & New York \\
\hline 46 & $5 / 8 / 2008$ & Carbon Asset Developer A & $\begin{array}{l}\text { Country Director of U.S. } \\
\text { Operations }\end{array}$ & New York \\
\hline 47 & $5 / 9 / 2008$ & Brokerage B & $\begin{array}{l}\text { Environmental Markets } \\
\text { Broker }\end{array}$ & New York \\
\hline
\end{tabular}




\begin{tabular}{|c|c|c|c|c|}
\hline $\begin{array}{l}\text { Interview } \\
\text { Number }\end{array}$ & Date & Organization Label & Interlocutor Position & $\begin{array}{l}\text { Interview } \\
\text { Location }\end{array}$ \\
\hline 48 & $5 / 9 / 2008$ & $\begin{array}{l}\text { Market Technology } \\
\text { Service Provider }\end{array}$ & $\begin{array}{l}\text { Managing Director, } \\
\text { Environmental Markets }\end{array}$ & New York \\
\hline 49 & $5 / 13 / 2008$ & Energy Supplier A & Director Supply Origination & New York \\
\hline 50 & $5 / 13 / 2008$ & Energy Supplier A & $\begin{array}{l}\text { Vice president Product } \\
\text { Management }\end{array}$ & New York \\
\hline 51 & $5 / 13 / 2008$ & Investment Bank A & $\begin{array}{l}\text { Vice President, Energy- } \\
\text { Trading and Environmental } \\
\text { Markets }\end{array}$ & New York \\
\hline 52 & $5 / 14 / 2008$ & Consultancy F & Sustainability Consultant & New York \\
\hline 53 & $5 / 14 / 2008$ & Consultancy F & Sustainability Consultant & New York \\
\hline 54 & $5 / 14 / 2008$ & Asset Manager & Associate & New York \\
\hline 55 & $5 / 14 / 2008$ & Investment Bank B & Carbon Sales Associate & New York \\
\hline 56 & $5 / 15 / 2008$ & Brokerage C & Managing Director & New York \\
\hline 57 & $5 / 16 / 2008$ & NGO A & Senior Finance Fellow & New York \\
\hline 58 & $5 / 16 / 2008$ & Venture Capital Fund & Managing Director & New York \\
\hline 59 & $5 / 20 / 2008$ & $\begin{array}{l}\text { Financial Services } \\
\text { Company C }\end{array}$ & $\begin{array}{l}\text { Hedge Fund Trading } \\
\text { Manager }\end{array}$ & Chicago \\
\hline 60 & $5 / 21 / 2008$ & Exchange $\mathrm{C}$ & Director & Chicago \\
\hline 61 & $5 / 21 / 2008$ & $\begin{array}{l}\text { Intergovernmental } \\
\text { Organization A }\end{array}$ & Policy Developer & $\begin{array}{l}\text { New York } \\
\text { (Phone) }\end{array}$ \\
\hline 62 & $5 / 22 / 2008$ & Retail Bank & $\begin{array}{l}\text { Principal, Global } \\
\text { Commodities }\end{array}$ & $\begin{array}{l}\text { New York } \\
\text { (Phone) }\end{array}$ \\
\hline 63 & $5 / 22 / 2008$ & Retail Bank & $\begin{array}{l}\text { Principal, Commodities } \\
\text { Group }\end{array}$ & $\begin{array}{l}\text { New York } \\
\text { (Phone) }\end{array}$ \\
\hline 64 & $5 / 22 / 2008$ & Legal Firm C & Partner & Chicago \\
\hline 65 & $5 / 22 / 2008$ & Exchange D & Senior Vice President & Chicago \\
\hline 66 & $5 / 22 / 2008$ & Exchange D & Derivatives Developer & Chicago \\
\hline 67 & $5 / 23 / 2008$ & NGO B & Associate Director & Chicago \\
\hline 68 & $5 / 23 / 2008$ & NGO B & Associate & Chicago \\
\hline 69 & $6 / 17 / 2008$ & Exchange $\mathrm{E}$ & Director of Business & Paris \\
\hline 70 & $6 / 30 / 2008$ & $\begin{array}{l}\text { Financial Services } \\
\text { Company D }\end{array}$ & $\begin{array}{l}\text { Director Environmental } \\
\text { Products }\end{array}$ & London \\
\hline
\end{tabular}




\begin{tabular}{|c|c|c|c|c|}
\hline $\begin{array}{l}\text { Interview } \\
\text { Number }\end{array}$ & Date & Organization Label & Interlocutor Position & $\begin{array}{l}\text { Interview } \\
\text { Location }\end{array}$ \\
\hline 71 & $6 / 30 / 2008$ & Investment Bank A & $\begin{array}{l}\text { Vice President Fixed Income } \\
\text { and Energy Trading }\end{array}$ & London \\
\hline 72 & $7 / 1 / 2008$ & Investment Bank J & $\begin{array}{l}\text { Associate Environmental } \\
\text { Products }\end{array}$ & London \\
\hline 73 & $7 / 1 / 2008$ & News Wire A & $\begin{array}{l}\text { Correspondent } \\
\text { Environmental Markets }\end{array}$ & London \\
\hline 74 & $7 / 1 / 2008$ & Multinational Oil Company & $\begin{array}{l}\text { Environmental Products, } \\
\text { Team Leader }\end{array}$ & London \\
\hline 75 & $7 / 1 / 2008$ & Multinational Oil Company & $\begin{array}{l}\text { Environmental Products, } \\
\text { Senior Trader }\end{array}$ & London \\
\hline 76 & $7 / 1 / 2008$ & $\begin{array}{l}\text { Government-funded } \\
\text { Carbon Services Firm }\end{array}$ & Chief Economist & London \\
\hline 77 & $7 / 2 / 2008$ & Carbon Rating Agency A & Associate, Strategic Advice & London \\
\hline 78 & $7 / 3 / 2008$ & Carbon Asset Developer D & $\begin{array}{l}\text { Senior Vice President, } \\
\text { Trading Group }\end{array}$ & London \\
\hline 79 & $7 / 3 / 2008$ & Legal Firm C & Partner & London \\
\hline 80 & $7 / 4 / 2008$ & $\begin{array}{l}\text { Financial Services } \\
\text { Company E }\end{array}$ & Vice President & London \\
\hline 81 & $7 / 4 / 2008$ & Carbon Rating Agency B & Director of Research, Europe & London \\
\hline 82 & $8 / 14 / 2008$ & $\begin{array}{l}\text { Global PSF/ Consultancy } \\
\text { D }\end{array}$ & Managing Director & Los Angeles \\
\hline 83 & $8 / 19 / 2008$ & Energy Supplier B & Climate Program Manager & Los Angeles \\
\hline 84 & $8 / 20 / 2008$ & NGO A & Project Attorney & San Francisco \\
\hline 85 & $8 / 20 / 2008$ & Sovereign Wealth Fund & Vice President & San Francisco \\
\hline 86 & $8 / 21 / 2008$ & $\begin{array}{l}\text { Financial Services } \\
\text { Company E }\end{array}$ & Managing Director & San Francisco \\
\hline 87 & $8 / 21 / 2008$ & Consultancy F & $\begin{array}{l}\text { Senior Sustainability } \\
\text { Consultant }\end{array}$ & San Francisco \\
\hline 88 & $8 / 22 / 2008$ & Regulatory Agency B & Senior Policy Advisor & Berkeley \\
\hline 89 & $8 / 22 / 2008$ & California Senate & Senior Policy Advisor & Sacramento \\
\hline 90 & $8 / 26 / 2008$ & California Congress & Policy Maker & Los Angeles \\
\hline 91 & $8 / 27 / 2008$ & Registry & $\begin{array}{l}\text { Vice President of Business } \\
\text { Development }\end{array}$ & Los Angeles \\
\hline 92 & $8 / 27 / 2008$ & Registry & Vice President of Policy & Los Angeles \\
\hline 93 & $9 / 08 / 2008$ & $\begin{array}{l}\text { U.S. House of } \\
\text { Representatives }\end{array}$ & Legislative Assistant & $\begin{array}{l}\text { Washington } \\
\text { D.C. }\end{array}$ \\
\hline
\end{tabular}




\begin{tabular}{|c|c|c|c|c|}
\hline $\begin{array}{l}\text { Interview } \\
\text { Number }\end{array}$ & Date & Organization Label & Interlocutor Position & $\begin{array}{l}\text { Interview } \\
\text { Location }\end{array}$ \\
\hline 94 & 9/08/2008 & NGO C & Climate Scientist & $\begin{array}{l}\text { Washington } \\
\text { D.C. }\end{array}$ \\
\hline 95 & 9/09/2008 & Legal Firm C & Partner & $\begin{array}{l}\text { Washington } \\
\text { D.C. }\end{array}$ \\
\hline 96 & 9/09/2008 & Legal Firm D & Partner & $\begin{array}{l}\text { Washington } \\
\text { D.C. }\end{array}$ \\
\hline 97 & 9/09/2008 & Asset Manager & Research Analyst & $\begin{array}{l}\text { Washington } \\
\text { D.C. }\end{array}$ \\
\hline 98 & $9 / 09 / 2008$ & NGO B & Policy Director & $\begin{array}{l}\text { Washington } \\
\text { D.C. }\end{array}$ \\
\hline 99 & 9/10/2008 & Legal Firm E & Attorney & $\begin{array}{l}\text { Washington } \\
\text { D.C. }\end{array}$ \\
\hline 100 & $9 / 10 / 2008$ & $\begin{array}{l}\text { Environmental Think Tank } \\
\text { B }\end{array}$ & Senior Associate & $\begin{array}{l}\text { Washington } \\
\text { D.C. }\end{array}$ \\
\hline 101 & $9 / 11 / 2008$ & Legal Firm F & Partner & $\begin{array}{l}\text { Washington } \\
\text { D.C. }\end{array}$ \\
\hline 102 & $9 / 11 / 2008$ & Trade Association & Director & $\begin{array}{l}\text { Washington } \\
\text { D.C. }\end{array}$ \\
\hline 103 & $9 / 12 / 2008$ & Legal Firm G & Attorney & $\begin{array}{l}\text { Washington } \\
\text { D.C. }\end{array}$ \\
\hline 104 & $9 / 12 / 2008$ & $\begin{array}{l}\text { Intergovernmental } \\
\text { Organization B }\end{array}$ & Senior Financial Specialist & $\begin{array}{l}\text { Washington } \\
\text { D.C. }\end{array}$ \\
\hline 105 & $9 / 12 / 2008$ & $\begin{array}{l}\text { Environmental Think Tank } \\
\text { B }\end{array}$ & Director & $\begin{array}{l}\text { Washington } \\
\text { D.C. }\end{array}$ \\
\hline 106 & $9 / 15 / 2008$ & Regulatory Agency C & Deputy Assistant Secretary & $\begin{array}{l}\text { Washington } \\
\text { D.C. }\end{array}$ \\
\hline 107 & $9 / 15 / 2008$ & $\begin{array}{l}\text { U.S. House of } \\
\text { Representatives }\end{array}$ & Legislative Assistant & $\begin{array}{l}\text { Washington } \\
\text { D.C. }\end{array}$ \\
\hline 108 & $9 / 15 / 2008$ & U.S. Senate & $\begin{array}{l}\text { Counsel and Legislative } \\
\text { Assistant }\end{array}$ & $\begin{array}{l}\text { Washington } \\
\text { D.C. }\end{array}$ \\
\hline 109 & $9 / 16 / 2008$ & U.S. Science Agency & Director & $\begin{array}{l}\text { Washington } \\
\text { D.C. }\end{array}$ \\
\hline 110 & 9/17/2008 & $\begin{array}{l}\text { Environmental Think Tank } \\
\text { C }\end{array}$ & Senior Fellow & $\begin{array}{l}\text { Washington } \\
\text { D.C. }\end{array}$ \\
\hline 111 & $10 / 08 / 2008$ & U.S. Senate & Senior Legislative Assistant & $\begin{array}{l}\text { Washington } \\
\text { D.C. (Phone) }\end{array}$ \\
\hline
\end{tabular}




\section{References}

Anderson, B. (1991). Imagined communities: Reflections on the origin and spread of nationalism. London and New York: Verso.

Baker McKenzie. (2009). "Baker \& McKenzie Launches CDM Rulebook" March 28, 2008. News Release Retrieved March 30, 2009 from http://www.bakernet.com/BakerNet/News/Archive/CDMRulebookLaunch

Bansal, P. (2003). From issues to actions: The importance of individual concerns and organizational values in responding to natural environmental issues. Organization Science, 14(5), 510-527.

Bansal, P., \& Howard, E. (Eds.). (1997). Business and the Natural Environment. Oxford: Butterworth-Heinemann.

Barley, S. R., \& Tolbert, P. S. (1997). Institutionalization and structuration: Studying the links between action and institution. Organization studies, 18(1), 93-117.

Barry, A., \& Slater, D. (2002). Technology, politics and the market: an interview with Michel Callon. Economy and Society, 31(2), 285 - 306.

Berry, J. M. (2003). Validity and Reliability Issues In Elite Interviewing. PS: Political Science and Politics, 35(04), 679-682.

Bourdieu, P. (1977). Outline of a Theory of Practice. Cambridge: Cambridge University Press.

Bourdieu, P., \& Wacquant, L. J. D. (1992). An invitation to reflexive sociology. Chicago: University of Chicago Press.

Callon, M. (1998). The laws of the markets Oxford: Blackwell Publishers.

Campbell, J. L., \& Lindberg, L. N. (1990). Property rights and the organization of economic activity by the state. American Sociological Review, 55(5), 634-647.

Capoor, K., \& Ambrosi, P. (2008). State and Trends of the Carbon Market, 2008. Washington D.C.: World Bank Carbon Finance Unit.

Carr, C., \& Rosembuj, F. (2007). World Bank Experiences in Contracting for Emissions Reductions. Environmental Liability, 2, 114-119.

Castells, M. (1996). The rise of the network society. Malden, MA; Oxford: Blackwell.

Clark, G. L. (1998). Stylized facts and close dialogue: Methodology in economic geography. Annals of the Association of American Geographers, 88(1), 73-87.

Coase, R. H. (1937). The nature of the firm. Economica, 4(16), 386-405.

Demsetz, H. (1967). Toward a theory of property rights. The American Economic Review, 57(2), 347-359.

DiMaggio, P. (1982). Cultural entrepreneurship in nineteenth-century Boston: The creation of an organizational base for high culture in America. Media, Culture \& Society, 4(1), 33-50.

DiMaggio, P. J., \& Powell, W. W. (1983). The iron cage revisited: Institutional isomorphism and collective rationality in organizational fields. American sociological review, 147-160.

Dobbin, F. (1994). Forging industrial policy: The United States, Britain, and France in the railway age. Cambridge: Cambridge university press.

Durkheim, E. (1933). The division of labor in society. New York: Macmillan.

Elam, M., \& Arrow, K. J. (1993). Markets, morals and powers of innovation. Economy and Society, 22(1), 1 - 41.

Fine, B., \& Lapavitsas, C. (2000). Markets and money in social theory: what role for economics? Economy and Society, 29(3), 357-382. 
Fligstein, N. (1996). Markets as politics: a political-cultural approach to market institutions. American Sociological Review, 61(4), 656-673.

Fligstein, N. (2001). The architecture of markets: an economic sociology of twenty-first-century capitalist societies. Princeton, N.J. ; Oxford: Princeton University Press.

Fligstein, N., \& Stone Sweet, A. (2002). Constructing Polities and Markets: An Institutionalist Account of European Integration 1. American Journal of Sociology, 107(5), 1206-1243.

Foucault, M. (2001). The order of things: An archaeology of the human sciences. London: Routledge.

Geertz, C. (1983). Local knowledge: Further essays in interpretive anthropology. New York: Basic Books.

GHGP. (2009). About the GHG Protocol. About the Greenhouse Gas Protocol Initiative Retrieved March 28, 2009 from http:/www.ghgprotocol.org/about-ghgp

Giddens, A. (1979). Central problems in social theory: Action, structure, and contradiction in social analysis. Berkeley: University of California Press.

Giddens, A. (1984). The constitution of society. Cambridge Polity Press

Goldstein, K. (2003). Getting in the Door: Sampling and Completing Elite Interviews. PS: Political Science and Politics, 35(04), 669-672.

Granovetter, M. (1985). Economic action and social structure: the problem of embeddedness. American journal of sociology, 91(3), 481.

Granovetter, M. (1994). Business Groups. In R. Swedberg, N. Smelser \& R. Swedberg (Eds.), The Handbook of Economic Sociology (pp. 453-475). Princeton, NJ: Princeton University Press.

Hamilton, K., Sjardin, M., Marcello, T., \& Xu, G. (2008). Forging a Frontier: State of the Voluntary Carbon Markets 2008. Washington, DC, and New York: Ecosystem Marketplace and New Carbon Finance.

Hasselknippe, H. (2003). Systems for carbon trading: an overview. Climate Policy, 3(1002), 4357.

Heugens, P. P., \& Lander, M. (2009). Structure! Agency!(And other quarrels): Meta-analyzing institutional theories of organization. Academy of Management Journal, 52(1), 61-85.

Hoffman, A. J. (2001). From heresy to dogma: An institutional history of corporate environmentalism: Stanford University Press.

Jacoby, S. M. (1990). The new institutionalism: what can it learn from the old? Industrial Relations, 29(2), 316-340.

Jepperson, R. L. (1991). Institutions, institutional effects, and institutionalism. In W. Powell \& P. DiMaggio (Eds.), The new institutionalism in organizational analysis (pp. 143-163). Chicago: Chicago University Press.

Knorr-Cetina, K., \& Preda, A. (2005). The sociology of financial markets. Oxford: Oxford University Press.

Knox-Hayes, J. (2008). Constructing Carbon Market Spacetime: Implications for NeoModernity. SSRN: http://ssrn.com/paper=1292323

Knox-Hayes, J. (2009). Path Dependence, Coalitions and Interlinked Networks: Legislating Carbon Markets in the Face of Financial Crisis. SSRN: http://papers.ssrn.com/sol3/papers.cfm?abstract_id=1352382.

Knox-Hayes, J. (Forthcoming 2009). The Developing Carbon Financial Service Industry: Expertise, Adaptation and Complementarity in London and New York. Journal of Economic Geography. 
Levy, D. L., \& Egan, D. (2003). A Neo-Gramscian Approach to Corporate Political Strategy: Conflict and Accommodation in the Climate Change Negotiations. Journal of Management Studies, 40(4), 803-829.

Lie, J. (1997). Sociology of markets. Annual Review of Sociology, 23(1), 341-360.

MacKenzie, D. (2006). An engine, not a camera: how financial models shape markets. Cambridge, Mass.; London: MIT Press.

MacKenzie, D. (2007). Finding the Ratchet: The Political Economy of Carbon Trading. London Review of Books, 29(7), April 5, 2007.

MacKenzie, D. (2009a). Constructing Emissions Markets. In Material Markets: How Economic Agents are Constructed (pp. 137-176). Oxford: Oxford University Press.

MacKenzie, D. (2009b). Material Markets: How Economic Agents Are Constructed. Oxford: Oxford University Press.

Martin, R. (1994). Stateless monies, global financial integration and national economic autonomy: the end of geography. In S. Corbridge, N. Thrift \& R. Martin (Eds.), Money, power and space (pp. 253-278). Oxford: Blackwell Publishing.

Marx, K. (1930). Capital, volume 1. Trans. E. and C. Paul. London: Dent.

Meyer, J. W. (1994). Rationalized environments. In R. Scott \& J. Meyer (Eds.), Institutional Environments and Organizations: Structural Complexity and Individualism (pp. 28-54). Thousand Oaks, CA: Sage.

North, D. C. (1990). Institutions, Institutional Change and Economic Performance. Cambridge: Cambridge University Press.

Parsons, T. ([1934] 1990). Prolegomena to a theory of social institutions. American Sociological Review, 55(3), 319-333.

Pierson, P. (1996). The new politics of the welfare state. World Politics, 48(2), 143-179.

Polanyi, K. (1944). The great transformation: Economic and political origins of our time. New York: Rinehart.

Quattrone, P. (2006). The Possibility of the Testimony: A Case for Case Study Research. Organization, 13(1), 143.

Rutherford, M. (1995). The old and the new institutionalism: can bridges be built? Journal of Economic Issues, 29(2), 443-451.

Saines, R. M. (2006). "Carbon Market Overview Legal Issues and Opportunities" July 26, 2006. Baker and McKenzie, NAEM Conference Retrieved March 282009 from http://www.naem.org/Rick\%20Saines.pdf

Scott, W. R. (2001). Institutions and organizations. Thousand Oaks: Sage Publications.

Scott, W. R., \& Meyer, J. W. (1994). Institutional environments and organizations: Structural complexity and individualism. Thousand Oaks: Sage.

Scott, W. R., Ruef, M., Mendel, P., \& Caronna, C. (2000). Institutional change and organizations: Transformation of a healthcare field. Chicago: Chicago University Press.

Selznick, P. (1996). Institutionalism" old" and" new". Administrative science quarterly, 41(2), 270-277.

Skjurseth, J. B., \& Wettestad, J. r. (2007). EU emissions trading : initiation, decision-making and implementation. Burlington, VT: Ashgate Pub. Company.

Stinchcombe, A. L. (1965). Social Structure and Organizations. In J. G. March (Ed.), Handbook of Organizations (pp. 142-193). Chicago: Rand McNally.

Strauss, A. L., \& Corbin, J. M. (1998). Basics of Qualitative Research: Techniques and Procedures for Developing Grounded Theory: Sage Publications Inc. 
Tolbert, P. S., \& Zucker, L. G. (1996). The institutionalization of institutional theory. In S. Clegg, C. Hardy \& W. R. Nord (Eds.), Handbook of organization studies (pp. 175-190). Thousand Oaks California: Sage Publications.

Uzzi, B. (1999). Embeddedness in the making of financial capital: How social relations and networks benefit firms seeking financing. American sociological review, 64(4), 481-505. Watanabe, R., \& Robinson, G. (2005). The European Union Emissions Trading Scheme (EU ETS). Climate Policy, 5, 10-14.

Weber, K., Davis, G. F., \& Lounsbury, M. (Forthcoming 2009). Policy as myth and ceremony? The global spread of stock exchanges, 1980-2005. Academy of Management Journal. Weber, M. (1968). Economy and Society (edited by G. Roth and C. Wittich). New York: Bedminster.

\footnotetext{
${ }^{\mathrm{i}}$ I shall discuss at length the definition of social institutions in Section 2. For the time being, thinking of social institutions as a system of regulative norms shaping actual and expected human interaction will suffice.

${ }^{\text {ii }}$ For a history of the development of emissions trading and overview of the operation of the existent cap and trade mechanisms see (MacKenzie, 2009a).

iii It should be noted that the market for trading emissions is also growing in other areas such as Japan and Australia, and that United Nations Framework Convention on Climate Change (UNFCCC) Certified Emissions Reductions (CER) are produced through the Clean Development Mechanism (CDM) around the globe (Carr \& Rosembuj, 2007). However, for reasons of scope, the focus of this article is the trade and financialization of carbon emissions reduction credits in the United States and Europe.

iv There has been little systematic attempt to characterize the social relations within markets generally (for a preliminary attempt see Lie, 1997 and Granovetter 1994).
} 